\title{
Vitamin D deficiency and nutritional status in elderly hospitalized subjects in Iceland
}

\author{
Alfons Ramel ${ }^{1, *}$, Palmi V Jonsson ${ }^{2}$, Sigurbjorn Bjornsson ${ }^{2}$ and Inga Thorsdottir ${ }^{1}$ \\ 'Unit for Nutrition Research, Landspitali-University Hospital and Department of Food Science and Human \\ Nutrition, University of Iceland, Eiriksgata 29, 101 Reykjavik, Iceland: ${ }^{2}$ Departments of Geriatrics, \\ Landspitali-University Hospital and Faculty of Medicine, University of Iceland, Reykjavik, Iceland
}

Submitted 29 0ctober 2007: Accepted 18 November 2008: First published online 15 January 2009

\begin{abstract}
Objective: Poor nutrition and limited sunlight exposure (season) can be related to reduced serum 25-hydroxyvitamin D $(25(\mathrm{OH}) \mathrm{D})$ concentrations. Thus, elderly people in the Nordic countries might be at high risk for vitamin D deficiency. The aims of the study were to describe the prevalence of vitamin D deficiency in elderly hospitalized patients in Reykjavik, Iceland, and to investigate the effects of nutritional status and season on serum 25(OH)D.

Design: Cross-sectional study. Nutritional status was assessed and fasting blood was drawn and analysed for serum 25(OH)D and other clinical routine measurements. Setting: Departments of Geriatrics, Landspitali-University Hospital, Reykjavik, Iceland.

Subjects: Sixty hospitalized patients (mean age $83 \cdot 0$ (sD 7.9) years) were randomly assigned.

Results: Of the patients, $12 \cdot 3 \%$ suffered from vitamin D deficiency (serum $25(\mathrm{OH}) \mathrm{D}<25 \mathrm{nmol} / \mathrm{l}$ ) and $71.9 \%$ suffered from hypovitaminosis $\mathrm{D}$ (serum $25(\mathrm{OH}) \mathrm{D}=25-75 \mathrm{nmol} / \mathrm{l})$. There were no significant effects of gender or nutritional status on serum $25(\mathrm{OH}) \mathrm{D}$. Anthropometric variables correlated significantly with serum $25(\mathrm{OH}) \mathrm{D}$, but on stepwise linear regression modelling for the prediction of serum $25(\mathrm{OH}) \mathrm{D}$, BMI remained the only predictor variable $(B=-1 \cdot 454,95 \% \mathrm{CI}-2 \cdot 535,-0 \cdot 373, P=0 \cdot 009)$.

Conclusions: BMI was significantly negatively associated with serum $25(\mathrm{OH}) \mathrm{D}$ in hospitalized elderly patients. Neither nutritional status nor season significantly affected serum 25(OH)D in our patient group. Higher levels of serum 25(OH)D in elderly subjects with lower BMI are most likely explained by volume of distribution rather than by mobilization of vitamin $\mathrm{D}$ from its storage in adipose tissue due to age and disease-related catabolism.
\end{abstract}

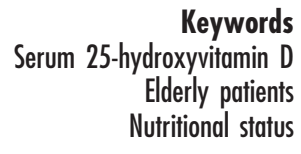

Because of changes that occur with ageing, older people are likely to have inadequate stores of vitamin $\mathrm{D}$. Issues such as reduced intestinal absorption ${ }^{(1)}$, inadequate diet, reduced sunlight exposure due to frailty, physiological changes associated with ageing, polypharmacy and diseases that interfere with vitamin D metabolism contribute to this risk ${ }^{(2)}$. Nutritional status measured by a comprehensive nutritional assessment has been found to be significantly associated with vitamin D deficiency (serum 25-hydroxyvitamin D (25(OH)D) concentrations) ${ }^{(3,4)}$. Multiple studies have estimated the prevalence of vitamin D deficiency in various elderly populations to be between $25 \%$ and $>80 \%{ }^{(5-9)}$.

The importance of vitamin D deficiency is related primarily to bone integrity and muscle strength, especially in the lower extremities. Because vitamin D is required for $\mathrm{Ca}$ homeostasis, secondary hyperparathyroidism may develop in patients with vitamin $\mathrm{D}$ deficiency. With increasing severity of vitamin D deficiency and secondary hyperparathyroidism, patients progress from states of increased bone turnover and decreased bone mass to states of impaired, and ultimately absent, mineralization with generalized osteomalacia $^{(10)}$. Considering that receptors for vitamin D exist in a large number of different cells, among them cardiomyocytes, vascular endothelial cells and immune cells, and the inverse associations of vitamin $\mathrm{D}$ with heart disease, hypertension and type 2 diabetes, makes vitamin $\mathrm{D}$ insufficiency (hypovitaminosis D) an even more important health issue ${ }^{(11)}$.

McKenna $^{(6)}$ has summarized a large number of studies from North America and Europe on vitamin D status in elderly subjects. Healthy elderly subjects had mean $25(\mathrm{OH}) \mathrm{D}$ concentrations in the insufficiency range throughout the year. In institutionalized subjects, most $25(\mathrm{OH}) \mathrm{D}$ concentrations were in the deficiency range. 
In Iceland, $25 \cdot 1 \%$ of those older than 80 years are institutionalized in nursing homes or geriatric departments (year 2007) ${ }^{(12)}$. Because solar UVB is the major source of vitamin $\mathrm{D}$ in man, it can be hypothesized that institutionalized elderly people in the Nordic countries are at especially high risk for vitamin D deficiency. The winter months in these countries are characterized by few or no hours of sunlight per day. In order to gain more knowledge on vitamin D status in the elderly, the present study aimed to investigate hospitalized elderly persons from a Nordic population (Reykjavik, Iceland; latitude $64^{\circ} 4^{\prime} \mathrm{N}$ ) and determine: (i) the prevalence of vitamin D deficiency in these subjects; (ii) the possible associations between serum $25(\mathrm{OH}) \mathrm{D}$ and nutritional status; and (iii) predictors of serum $25(\mathrm{OH}) \mathrm{D}$ using multiple regression analysis.

\section{Experimental methods}

\section{Subjects}

Sixty hospitalized long-stay patients with multiple morbid conditions from the Departments of Geriatrics were randomly assigned to participate in the study in the period from June 2002 to March 2003. The patients were cognitively intact but had multiple diseases and medications at the same time. Typically the main diagnoses were fractures such as hip fractures, chronic obstructive lung disease, heart failure and strokes. Frequently, patients suffered from infections such as urinary tract infection or pneumonia. The subjects represent typical patients within a geriatric hospital department for the non-demented. This cohort was originally used to compare various nutritional assessment tools ${ }^{(13)}$. Power calculations done for the present analysis showed that the standard deviation of serum $25(\mathrm{OH}) \mathrm{D}$ of $22 \mathrm{nmol} / \mathrm{l}$ allowed detection of differences between groups of $16 \mathrm{nmol} / 1$ or more (power $=0.8$, $P<0 \cdot 05)$. The inclusion criterion was age $>65$ years; exclusion criteria were severe cognitive impairment and failure to provide written consent for study participation. The study protocol was approved by the Local Ethical Committee of Landspitali-University Hospital in Reykjavik, Iceland, where the study was conducted.

\section{Assessment of nutritional status}

Full nutritional assessment, as used previously in various patient groups ${ }^{(13,14)}$, included seven variables: BMI (kg/ $\mathrm{m}^{2}$ ), information on unplanned weight loss, triceps skinfold thickness, mid-arm muscle circumference, serum albumin, serum prealbumin and total lymphocyte count, all of which are variables associated with malnutrition and clinical outcomes such as duration of hospital stay and mortality, and are therefore accepted as indicators of nutritional status ${ }^{(13,14)}$. Patients were defined as malnourished when at least three of the seven parameters were below reference values. The lower reference value for BMI was $20 \mathrm{~kg} / \mathrm{m}^{2}$. Reference values for skinfold thickness and mid-arm muscle circumference were derived from the 5 th percentile of the National Health and Nutrition Examination Survey (1971-4) population, standardized for age and sex. Unplanned weight loss was defined as weight loss of $>5 \%$ without intention in the three previous months. Reference values for this age group used by the hospital laboratory were 31-51 g/1 for serum albumin, 180-450 mg/l for serum prealbumin and $1.82 \times 10^{9} / 1$ for total lymphocyte count. Subjects were grouped accordingly as well-nourished or malnourished.

\section{Measurements and analytical methods}

The patients were asked their height and weight was measured in the hospital using standardized scales, from which BMI was calculated. The patients were also asked about nutritional issues (e.g. loss of appetite). Mid-arm circumference (MAC) was measured using a tape measure and triceps skinfold thickness was measured with skinfold callipers. These measurements were used to calculate mid-arm muscle circumference (MAMC) as follows: MAMC $=$ MAC $-\pi \times$ skinfold thickness. Blood samples were drawn after an overnight fast and analysed for lymphocytes, albumin, prealbumin, serum 25(OH)D concentration, blood lipids and serum creatinine at the laboratory of Landspitali-University Hospital in Reykjavik. Lymphocytes were measured by a Coulter STKS (Coulter Electronics Ltd, Hialeah, FL, USA) and by volumeconductivity scatter. Serum albumin was measured by the Kodak Ektachem colorimetric test (Eastman Kodak Co., Rochester, NY, USA). Serum prealbumin was measured by the Beckmann (Munich, Germany) prealbumin reagent test using rate nephelometry. Creatinine was measured by standard dry chemistry methodology on a Vitros 750 XRC 700 analyser (Johnson \& Johnson Co., Rochester, NY, USA). 25(OH)D levels were measured using RIA (DiaSorin, Stillwater, MN, USA). Inter-assay variations were $6.9 \%$ and $8.5 \%$ for serum 25(OH)D levels of 37 and $127 \mathrm{nmol} / 1$, respectively. Subjects were grouped into vitamin $\mathrm{D}$ deficiency $(25(\mathrm{OH}) \mathrm{D}<25 \mathrm{nmol} / \mathrm{l})$, hypovitaminosis $\mathrm{D}(25(\mathrm{OH}) \mathrm{D}=25-75 \mathrm{nmol} / \mathrm{l})$ or normal vitamin $\mathrm{D}(25(\mathrm{OH}) \mathrm{D} \geq 75 \mathrm{nmol} / \mathrm{l})^{(15)}$.

\section{Statistical analysis}

The data were analysed using the SPSS statistical software package version 11.0 (SPSS Inc., Chicago, IL, USA). Data are described as means and standard deviations. Distributions of all continuous variables were normal according to the Kolmogorov-Smirnov test. Differences between groups (e.g. well-/malnourished, female/male) were calculated using the independent-samples $t$ test. Correlations between variables were calculated using the Pearson correlation coefficient $(r)$. In order to determine the variables predicting serum 25(OH)D, stepwise linear regression analysis was done. Gender, season and variables which were associated $(P<0 \cdot 1)$ with serum $25(\mathrm{OH}) \mathrm{D}$ in the bivariate analysis were used in the regression model. 
If independent variables correlated with each other, the one which correlated most strongly with serum 25(OH)D was used in the regression analysis. Residuals were checked for normality using the Kolmogorov-Smirnov test. $P<0.05$ was regarded as statistically significant.

\section{Results}

Mean serum 25(OH)D was 50.6 (sD 22.5) nmol/1 (minimum $11.9 \mathrm{nmol} / 1$, maximum $97 \cdot 3 \mathrm{nmol} / \mathrm{l})$. Of the patients, $12 \cdot 3 \%$ suffered from vitamin D deficiency, $71.9 \%$ suffered from hypovitaminosis D and $15 \cdot 8 \%$ were in the normal range. Vitamin $\mathrm{D}$ concentrations in patients grouped by nutritional status, season, unplanned weight loss and loss of appetite can be seen in Table 1.

The mean age of the patients was 83.0 (SD 7.9) years. Malnourishment was diagnosed for thirty-five patients (58.3\%) by full nutritional assessment. Malnourished patients had lower BMI, serum albumin, prealbumin, triceps skinfold thickness and mid-arm muscle circumference and were older than well-nourished patients. Only one patient had received enteral or parenteral nutrition, respectively.

The length of hospitalization was very variable (range 3-638d) and not significantly different between subjects with vitamin D deficiency, hypovitaminosis D or normal vitamin D status (125 (SD 152), 80 (SD 64) and 120 (SD 141) d, respectively; $P>0 \cdot 05)$. Serum $25(\mathrm{OH}) \mathrm{D}$ correlated or tended to correlate with anthropometric variables and HDL cholesterol (Table 2).

Regression analysis was performed with serum $25(\mathrm{OH}) \mathrm{D}$ as the dependent variable and the following independent variables: gender, season, glomerular filtration rate, loss of appetite and BMI. HDL cholesterol was not entered because it correlated not only with serum $25(\mathrm{OH}) \mathrm{D}$, but also with BMI (collinearity problem). Only BMI remained a significant predictor (Fig. 1) after adjustment for these factors. $R^{2}$ was $11.7 \%$ and the residuals were normally distributed $(P=0 \cdot 908)$.

Table 1 Serum 25-hydroxyvitamin D (25(OH)D) concentrations in elderly hospitalized patients ( $n$ 60), Reykjavik, Iceland, 2002-3

\begin{tabular}{|c|c|c|c|}
\hline & \multicolumn{2}{|c|}{$25(\mathrm{OH}) \mathrm{D}(\mathrm{nmol} / \mathrm{l})$} & \multirow[b]{2}{*}{$P$ value* } \\
\hline & Mean & SD & \\
\hline Male ( $n$ 22; 36.7\%) & $50 \cdot 0$ & $22 \cdot 2$ & 0.869 \\
\hline Female (n 38; 63.3\%) & $51 \cdot 0$ & $23 \cdot 0$ & \\
\hline Well-nourished ( $n 25 ; 41 \cdot 7 \%$ ) & $46 \cdot 4$ & $21 \cdot 5$ & $0 \cdot 217$ \\
\hline Malnourished ( $n$ 35; 58.3\%) & $53 \cdot 9$ & $23 \cdot 0$ & \\
\hline Summer season (n 26; 43.3\%) & $55 \cdot 0$ & $24 \cdot 1$ & 0.093 \\
\hline Winter season ( $n 34 ; 56 \cdot 7 \%)$ & $44 \cdot 9$ & $19 \cdot 3$ & \\
\hline Unplanned weight loss ( $n 17 ; 28 \cdot 3 \%$ ) & $51 \cdot 5$ & $25 \cdot 3$ & $0 \cdot 858$ \\
\hline No weight loss ( $n 43 ; 71 \cdot 7 \%$ ) & $50 \cdot 3$ & $21 \cdot 6$ & \\
\hline Loss of appetite ( $n 23 ; 38 \cdot 3 \%$ ) & $57 \cdot 6$ & $23 \cdot 8$ & $0 \cdot 072$ \\
\hline Good appetite (n 37; 61·7\%) & $46 \cdot 5$ & $21 \cdot 0$ & \\
\hline
\end{tabular}

*Independent-samples $t$ test.

\section{Discussion}

The prevalence of vitamin D deficiency was $12 \cdot 3 \%$ and of hypovitaminosis D was $71.9 \%$ in our group of elderly long-stay hospital patients in Iceland with a mean hospitalization length of $107 \mathrm{~d}$. Because vitamin D status is related to bone health and is an important health factor, these findings underline the importance of targeted nutrition or vitamin D supplementation for disease prevention in elderly patients.

Table 2 Correlations* between serum 25-hydroxyvitamin D $(25(\mathrm{OH}) \mathrm{D})$ concentrations, anthropometric variables and blood lipids in elderly hospitalized patients ( $n 60)$, Reykjavik, Iceland, 2002-3

\begin{tabular}{clc}
\hline & & $\begin{array}{c}\text { 25(OH)D (nmol/l) } \\
\text { (range 11.9-97.3 mmol/l) }\end{array}$ \\
\hline Age (years) & $r$ & 0.197 \\
(range 66-105) years & $P$ value & 0.141 \\
BMI $\left(\mathrm{kg} / \mathrm{m}^{2}\right)$ & $r$ & -0.342 \\
$\left(\right.$ range $\left.16.5-40.9 \mathrm{~kg} / \mathrm{m}^{2}\right)$ & $P$ value & 0.009 \\
MAMC $(\mathrm{cm})$ & $r$ & -0.319 \\
$\quad$ (range $14.3-35.4 \mathrm{~cm})$ & $P$ value & 0.016 \\
Total cholesterol $(\mathrm{mmol} / \mathrm{l})$ & $r$ & 0.020 \\
(range 3.0-7.6 mmol/) & $P$ value & 0.883 \\
HDL cholesterol $(\mathrm{mmol} / \mathrm{l})$ & $r$ & 0.335 \\
(range 0.67-3.03 mmol/l) & $P$ value & 0.011 \\
Days of hospitalization & $r$ & 0.014 \\
(range 3-638 d) & $P$ value & 0.924 \\
\hline
\end{tabular}

MAMC, mid-arm muscle circumference.

${ }^{*}$ Pearson correlation coefficient, $r$.

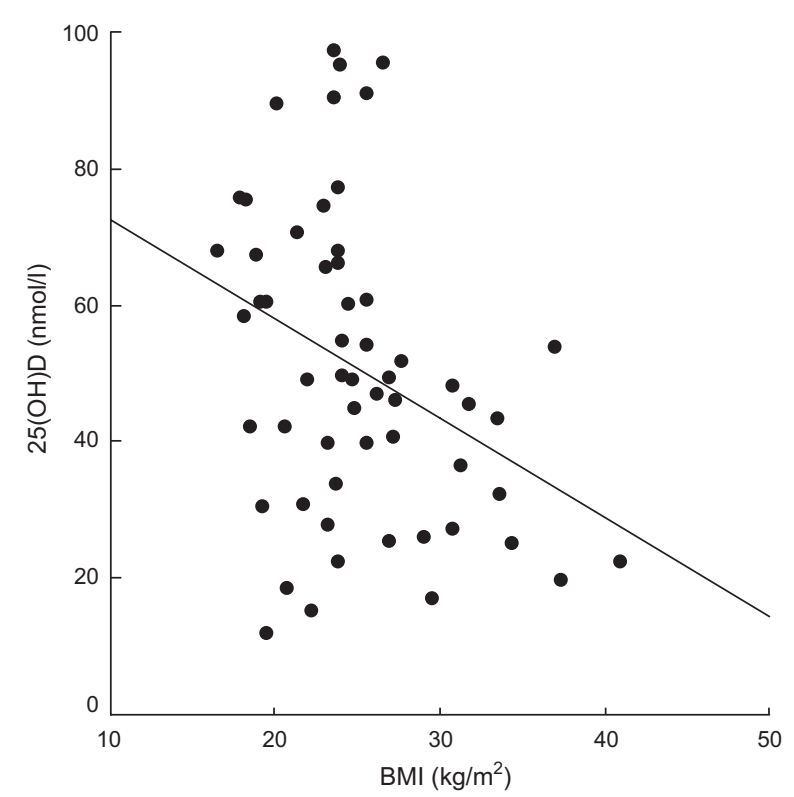

Fig. 1 Linear regression model for the prediction of serum 25-hydroxyvitamin D $(25(\mathrm{OH}) \mathrm{D})$ concentrations among elderly hospitalized patients ( $n$ 60), Reykjavik, Iceland, 2002-3 ( $B=$ $\left.-1 \cdot 454,95 \% \mathrm{Cl}-2 \cdot 535,-0.373, P=0.009 ; R^{2}=11 \cdot 7 \%\right)$ 
It has been shown that serum $25(\mathrm{OH}) \mathrm{D}$ concentrations decrease progressively with advancing age ${ }^{(16,17)}$. Prevalence data from other studies on vitamin D deficiency in hospitalized patients range from $25 \%$ up to $>80 \%$, although direct comparison is difficult due to differences in the cut-off values used. In a US study, a high prevalence ( $57 \%$ ) of vitamin D deficiency (cut-off value $<37 \cdot 5 \mathrm{nmol} / \mathrm{l}$ ) was found in unselected general medical inpatients ${ }^{(4)}$. In an Italian study (cut-off value of $20 \cdot 0 \mathrm{nmol} / \mathrm{l}$ ), the highest prevalence of vitamin D deficiency was found in a group of patients engaged in long-term rehabilitation programmes, ranging from $57 \cdot 8 \%$ in summer to $82 \cdot 3 \%$ in winter ${ }^{(9)}$. This shows that the problem of vitamin $\mathrm{D}$ deficiency in patients in hospital in Iceland is more widespread than previously appreciated.

The mean 25(OH)D concentration was $\sim 50 \mathrm{nmol} / 1$ in our patients, which is in good agreement with results from a recent Icelandic cross-sectional study (subjects aged 70-85 years) on vitamin D status based on the investigation of a random selection from the computerized population register of Reykjavik ${ }^{(18)}$. It is important to note that only two subjects of our group received enteral/ parenteral nutrition. Such nutrition formula feeds include multivitamin solutions containing appropriate amounts of the vitamin. Considering the high latitude of Reykjavik $\left(64^{\circ} 4^{\prime} \mathrm{N}\right)$ and the mean hospitalization length of $107 \mathrm{~d}$, an even more adverse outcome could have been expected. In the SENECA study, a unexpectedly positive relationship between serum 25(OH)D and geographic latitude was observed in the elderly subjects. This paradox can be explained by different dietary and other lifestyle habits. Elderly people living in Scandinavia and South Europe seem to differ in their fatty fish consumption, use of vitamin supplements and frequency of sun exposure ${ }^{(19)}$. It is therefore possible that regular fish oil and fatty fish consumption in our subjects prevents a higher prevalence of vitamin D deficiency. According to the Icelandic National Dietary Survey of $2002^{(20)}$, the mean daily fish consumption in elderly women and men is 47 and $65 \mathrm{~g}$, respectively, and the mean daily fish oil intake is $2 \mathrm{~g}$ for both genders. Around two-thirds of the dietary vitamin D in Iceland is supplied by fish and fish oil. In the age group $70-80$ years the mean vitamin D intake reaches $10 \cdot 2$ and $7 \cdot 2 \mu \mathrm{g} / \mathrm{d}$ for men and women, respectively. The Nordic Nutrient Recommendations 2004 recommend $15 \mu \mathrm{g} / \mathrm{d}$ for both genders.

The difference in serum $25(\mathrm{OH}) \mathrm{D}$ between summer and winter seasons was small $(\sim 10 \mathrm{nmol} / \mathrm{l})$ and not statistically significant in the present study, which lacked the power to determine whether such small differences were significant $(P=0 \cdot 093)$. Seasonal differences in serum $25(\mathrm{OH}) \mathrm{D}$ are commonly seen ${ }^{(4,9,18)}$, with twofold higher $25(\mathrm{OH}) \mathrm{D}$ concentrations after the summer than after the winter, but varying with various patient groups or study subjects ${ }^{(9)}$. Several reasons could be responsible for the absence of such variation in long-stay patients: (i) the lack of sunshine exposure accounts for the lack of seasonal variation in vitamin D status as has been reported previously ${ }^{(9)}$; (ii) summers in Iceland are often cold and windy, so that people remain fully dressed and the exposed skin area does not differ in summer from that in winter; and (iii) cod-liver oil might overwhelm the effects of seasonal variation in such a northern country. Cod-liver oil is offered daily along with breakfast at the Departments of Geriatrics although the intake is voluntary.

In the regression model BMI was the only significant predictor for serum $25(\mathrm{OH}) \mathrm{D}$. According to the model, serum $25(\mathrm{OH}) \mathrm{D}$ decreased by $\sim 1.5 \mathrm{nmol} / 1$ for each increase in BMI by $1 \mathrm{~kg} / \mathrm{m}^{2}$. However, the statistical model predicted only about $12 \%$ of the variability in serum 25(OH)D.

Although BMI is an indicator of nutritional status in the elderly in general, we observed a negative association between serum 25(OH)D and BMI. Such negative associations have been observed in obese individuals ${ }^{(21,22)}$ and we did not expect to see that negative association in our group because only $16 \cdot 7 \%$ of the subjects were obese. The aetiology of reduced serum $25(\mathrm{OH}) \mathrm{D}$ in the obese is unknown although various explanations for this observation have been proposed, including decreased sun exposure of obese individuals, increased volume of distribution and physiological adaptation to the need for more bone mass to support the increased weight. The true clinical significance of these abnormalities is unknown $^{(23-25)}$. It has been reported that poorer vitamin D status does not appear to be due to differences in dietary intake in the elderly, although reduced absorption of dietary vitamin $\mathrm{D}$ has been reported in this group ${ }^{(26)}$. The former suggestion is supported by our finding that patients with loss of appetite did not have lower serum $25(\mathrm{OH}) \mathrm{D}$ than patients with good appetite. In our group malnourished subjects tended to have higher serum $25(\mathrm{OH}) \mathrm{D}$ than their counterparts. Thus, the higher serum $25(\mathrm{OH}) \mathrm{D}$ in subjects with lower BMI in our group might indicate mobilization of vitamin D from its stores due to age and disease-related catabolism. This hypothesis is supported by an animal study (Wistar rats), in which the effects of feeding and fasting on circulating $25(\mathrm{OH}) \mathrm{D}$ were investigated. Fasting caused increased plasma NEFA, weight loss and raised plasma $25(\mathrm{OH}) \mathrm{D}$ in comparison to animals in energy balance ${ }^{(27)}$. However, our patients who had experienced unintended weight loss did not have higher serum $25(\mathrm{OH}) \mathrm{D}$ than patients without previous weight loss, thus indicating that not catabolism but rather volume of distribution plays a significant part in determining serum $25(\mathrm{OH}) \mathrm{D}$ concentrations.

\section{Limitations}

In the present study we did not measure dietary or supplemental vitamin D intake of the subjects and we cannot therefore investigate the effect of dietary vitamin $\mathrm{D}$ on serum 25(OH)D concentrations. However, because only 
two subjects had received enteral/parenteral nutrition, the majority of the subjects received the same food from the hospital canteen. The sample size limits the power to detect possible effects of season on serum $25(\mathrm{OH}) \mathrm{D}$ levels.

\section{Conclusion}

The prevalence of vitamin D deficiency was $12 \cdot 3 \%$ and of hypovitaminosis D was $71.9 \%$ in our group of hospitalized elderly patients from an Icelandic hospital with a mean hospitalization length of $107 \mathrm{~d}$. BMI was significantly negatively associated with serum 25(OH)D in these elderly patients. Higher concentrations of serum $25(\mathrm{OH}) \mathrm{D}$ in elderly subjects with lower BMI are most likely explained by lower volumes of distribution rather than by increased mobilization of vitamin $\mathrm{D}$ from storage.

\section{Acknowledgements}

Sources of funding: The project was supported by the University of Iceland Research Fund. Conflict of interest declaration: None. Authorship responsibilities: A.R. (idea, data elaboration and analysis, manuscript preparation); P.V.J. (principal investigator, study design and manuscript preparation); S.B. (study design and manuscript preparation); I.T. (study design and manuscript preparation)

\section{References}

1. Barragry JM, France MW, Corless D, Gupta SP, Switala S, Boucher BJ \& Cohen RD (1978) Intestinal cholecalciferol absorption in the elderly and in younger adults. Clin Sci Mol Med 55, 213-220.

2. Gloth FM 3rd \& Tobin JD (1995) Vitamin D deficiency in older people. J Am Geriatr Soc 43, 822-888.

3. Vellas B, Guigoz Y, Baumgartner M, Garry PJ, Lauque S \& Albarede JL (2000) Relationships between nutritional markers and the Mini-Nutritional Assessment in 155 older persons. J Am Geriatr Soc 48, 1300-1309.

4. Thomas MK, Lloyd-Jones DM, Thadhani RI, Shaw AC, Deraska DJ, Kitch BT, Vamvakas EC, Dick IM, Prince RL \& Finkelstein JS (1998) Hypovitaminosis D in medical inpatients. $N$ Engl J Med 338, 777-783.

5. Omdahl JL, Garry PJ, Hunsaker LA, Hunt WC \& Goodwin JS (1982) Nutritional status in a healthy elderly population: vitamin D. Am J Clin Nutr 36, 1225-1233.

6. McKenna MJ (1992) Differences in vitamin D status between countries in young adults and the elderly. $A m \mathrm{~J}$ Med 93, 69-77.

7. Goldray D, Mizrahi-Sasson E, Merdler C, Edelstein-Singer M, Algoetti A, Eisenberg Z, Jaccard N \& Weisman Y (1989) Vitamin $\mathrm{D}$ deficiency in elderly patients in a general hospital. J Am Geriatr Soc 37, 589-592.

8. Gloth FM, Gundberg CM, Hollis BW, Haddad JG Jr \& Tobin JD (1995) Vitamin D deficiency in homebound elderly persons. JAMA 274, 1683-1686.

9. Romagnoli E, Caravella P, Scarnecchia L, Martinez P \& Minisola S (1999) Hypovitaminosis D in an Italian population of healthy subjects and hospitalized patients. Br J Nutr 81, 133-137.

10. Parfitt AM (1998) Osteomalacia and related disorders. In Metabolic Bone Disease, 3rd ed., pp. 327-386 [LV Avioli and SM Krane, editors]. San Diego, CA: Academic Press.

11. Zittermann A (2006) Vitamin D and disease prevention with special reference to cardiovascular disease. Prog Biophys Mol Biol 92, 39-48.

12. Statistics Iceland (2008) Occupants of retirement homes and nursing homes and wards by sex and age 1993-2007. http://www.statice.is/ (accessed December 2008).

13. Thorsdottir I, Jonsson PV, Asgeirsdottir AE, Hjaltadottir I, Bjornsson S \& Ramel A (2005) Fast and simple screening for nutritional status in hospitalized, elderly people. J Hum Nutr Diet 18, 53-60.

14. Thorsdottir I, Gunnarsdottir I \& Eriksen B (2001) Screening method evaluated by nutritional status measurements can be used to detect malnourishment in chronic obstructive pulmonary disease. J Am Diet Assoc 101, 648-654.

15. Gómez-Alonso C, Naves-Díaz ML, Fernández-Martín JL, Díaz-López JB, Fernández-Coto MT \& Cannata-Andía JB (2003) Vitamin D status and secondary hyperparathyroidism: the importance of 25-hydroxyvitamin D cut-off levels. Kidney Int Suppl 85, S44-S48.

16. Chapuy MC, Durr F \& Chapuy P (1983) Age-related changes in parathyroid hormone and 25 hydroxycholecalciferol levels. J Gerontol 38, 19-22.

17. Tsai KS, Wahner HW, Offord KP, Melton LJ 3rd, Kumar R \& Riggs BL (1987) Effect of aging on vitamin D stores and bone density in women. Calcif Tissue Int 40, 241-243.

18. Steingrimsdottir L, Gunnarsson O, Indridason OS, Franzson L \& Sigurdsson G (2005) Relationship between serum parathyroid hormone levels, vitamin D sufficiency, and calcium intake. JAMA 294, 2336-2341.

19. Lips P (2005) How to define normal values for serum concentrations of 25 hydroxyvitamin D? An overview. In Vitamin D, 2nd ed., pp. 1019-1928 [D Feldman, JW Pike and FH Glorieux, editors]. Amsterdam: Elsevier Academic Press.

20. Steingrimsdottir L, Thorgeirsdottir H \& Olafsdottir AS (2002) The Diet of Icelanders - Dietary Survey of The Icelandic Nutrition Council 2002. Reykjavik: Lydheislustod.

21. Carlin AM, Rao DS, Meslemani AM, Genaw JA, Parikh NJ, Levy S, Bhan A \& Talpos GB (2006) Prevalence of vitamin D depletion among morbidly obese patients seeking gastric bypass surgery. Surg Obes Relat Dis 2, 98-103.

22. Yanoff LB, Parikh SJ, Spitalnik A, Denkinger B, Sebring NG, Slaughter P, McHugh T, Remaley AT \& Yanovski JA (2006) The prevalence of hypovitaminosis $\mathrm{D}$ and secondary hyperparathyroidism in obese Black Americans. Clin Endocrinol (Oxf) 64, 523-529.

23. Bell NH, Epstein S, Greene A, Shary J, Oexmann MJ \& Shaw $S$ (1985) Evidence for alteration of the vitamin D-endocrine system in obese subjects. J Clin Invest 76, 370-373.

24. Compston JE, Vedi S, Ledger JE, Webb A, Gazet JC \& Pilkington TR (1981) Vitamin D status and bone histomorphometry in gross obesity. Am J Clin Nutr 34, 2359-2363.

25. Wortsman J, Matsuoka LY, Chen TC, Lu Z \& Holick MF (2000) Decreased bioavailability of vitamin D in obesity. Am J Clin Nutr 72, 690-693.

26. Elia M \& Stratton RJ (2005) Geographical inequalities in nutrient status and risk of malnutrition among English people aged 65 y and older. Nutrition 21, 1100-1106.

27. Brouwer DA, van Beek J, Ferwerda H, Brugman AM, van der Klis FR, van der Heiden HJ \& Muskiet FA (1998) Rat adipose tissue rapidly accumulates and slowly releases an orallyadministered high vitamin D dose. Br J Nutr 79, 527-532. 